\title{
Is there a role for ischaemic conditioning in cardiac surgery?
}

\section{[version 1; peer review: 3 approved]}

\author{
Luciano Candilio 1,2, Derek Hausenloy (DD1-6
}

${ }^{1}$ The Hatter Cardiovascular Institute, Institute of Cardiovascular Science, University College London, London, UK
${ }^{2}$ The National Institute of Health Research-University College London Hospitals Biomedical Research Centre, London, UK
${ }^{3}$ Barts Heart Centre, St Bartholomew's Hospital, London, UK
${ }^{4}$ Cardiovascular and Metabolic Disorders Program, Duke-National University of Singapore Medical School, Singapore, Singapore
${ }^{5}$ National Heart Research Institute Singapore, National Heart Centre, Singapore, Singapore
${ }^{6}$ Yong Loo Lin School of Medicine, National University Singapore, Singapore, Singapore

V1 First published: 25 Apr 2017, 6(F1000 Faculty Rev):563

https://doi.org/10.12688/f1000research.10963.1

Latest published: 25 Apr 2017, 6(F1000 Faculty Rev):563

https://doi.org/10.12688/f1000research.10963.1

\section{Abstract}

Coronary artery disease (CAD) is a major cause of morbidity and mortality worldwide. Coronary artery bypass graft (CABG) surgery is the revascularisation strategy of choice in patients with diabetes mellitus and complex CAD. Owing to a number of factors, including the ageing population, the increased complexity of CAD being treated, concomitant valve and aortic surgery, and multiple comorbidities, higher-risk patients are being operated on, the result of which is an increased risk of sustaining perioperative myocardial injury (PMI) and poorer clinical outcomes. As such, new treatment strategies are required to protect the heart against PMI and improve clinical outcomes following cardiac surgery. In this regard, the heart can be endogenously protected from PMI by subjecting the myocardium to one or more brief cycles of ischaemia and reperfusion, a strategy called "ischaemic conditioning". However, this requires an intervention applied directly to the heart, which may be challenging to apply in the clinical setting. In this regard, the strategy of remote ischaemic conditioning (RIC) may be more attractive, as it allows the endogenous cardioprotective strategy to be applied away from the heart to the arm or leg by simply inflating and deflating a cuff on the upper arm or thigh to induce one or more brief cycles of ischaemia and reperfusion (termed "limb RIC"). Although a number of small clinical studies have demonstrated less PMI with limb RIC following cardiac surgery, three recently published large multicentre randomised clinical trials found no beneficial effects on short-term or long-term clinical outcomes, questioning the role of limb RIC in the setting of cardiac surgery. In this article, we review ischaemic conditioning as a therapeutic strategy for endogenous cardioprotection in patients undergoing cardiac surgery and discuss the potential reasons for the failure of limb RIC to improve clinical outcomes in this setting. Crucially, limb RIC still has the therapeutic

\section{Open Peer Review}

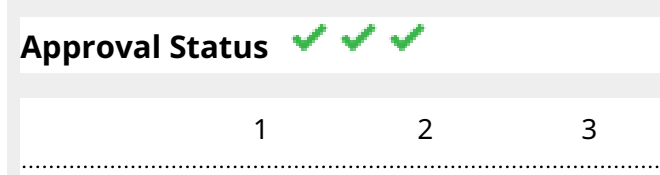

\section{version 1}

25 Apr 2017

Faculty Reviews are review articles written by the prestigious Members of Faculty Opinions. The articles are commissioned and peer reviewed before publication to ensure that the final, published version is comprehensive and accessible. The reviewers who approved the final version are listed with their names and affiliations.

1. Fabrice Prunier, Department of Cardiology, CHU Angers, Angers, France

\section{Andreas Goetzenich, RWTH Aachen}

University, Aachen, Germany

3. Petra Kleinbongard, West German Heart and Vascular Centre, University of Essen Medical School, Essen, Germany Any comments on the article can be found at the end of the article. 
potential to protect the heart in other clinical settings, such as acute myocardial infarction, and it may also protect other organs against acute ischaemia/reperfusion injury (such as the brain, kidney, and liver).

\section{Keywords}

ischemic preconditioning, ischemic postconditioning, remote ischemic conditioning

Corresponding author: Derek Hausenloy (d.hausenloy@ucl.ac.uk)

Competing interests: The authors declare that they have no competing interests.

Grant information: This work was supported by the British Heart Foundation (FS/10/039/28270), the Rosetrees Trust, Duke-NUS Medical School, and the National Institute for Health Research University College London Hospitals Biomedical Research Centre.

The funders had no role in study design, data collection and analysis, decision to publish, or preparation of the manuscript.

Copyright: $\odot 2017$ Candilio L and Hausenloy D. This is an open access article distributed under the terms of the Creative Commons Attribution License, which permits unrestricted use, distribution, and reproduction in any medium, provided the original work is properly cited. Data associated with the article are available under the terms of the Creative Commons Zero "No rights reserved" data waiver (CC0 1.0 Public domain dedication).

How to cite this article: Candilio $L$ and Hausenloy $D$. Is there a role for ischaemic conditioning in cardiac surgery? [version 1; peer review: 3 approved] F1000Research 2017, 6(F1000 Faculty Rev):563 https://doi.org/10.12688/f1000research.10963.1

First published: 25 Apr 2017, 6(F1000 Faculty Rev):563 https://doi.org/10.12688/f1000research.10963.1 


\section{Introduction}

Coronary artery disease (CAD) remains a leading cause of morbidity and mortality worldwide. For patients with complex multi-vessel CAD, coronary artery bypass graft (CABG) surgery is the revascularisation strategy of choice, as it offers survival advantage when compared to multi-vessel percutaneous coronary intervention $(\mathrm{PCI})^{1,2}$. Although advances in surgical and cardioprotection techniques have resulted in improved clinical outcomes following $\mathrm{CABG}$ surgery, changes in patient demographics have meant that higher-risk patients are now undergoing CABG surgery, all which have resulted in an increased risk of perioperative myocardial injury (PMI), which is detected by the release of serum cardiac biomarkers such as CK-MB, troponin $\mathrm{I}$, and troponin $\mathrm{T}$, and a higher operative mortality risk of $5-6 \%{ }^{3}$. These changes include (a) the ageing population (the proportion of patients over 75 years old has increased by more than 4.5-fold over the last decade with a 5-year mortality in this age group of $35 \%$ ), (b) the presence of co-morbidities such as diabetes and hypertension (the proportion of diabetic patients has risen from $15 \%$ to $22 \%$, with an operative mortality of $2.6 \%$ ), (c) more complex CAD is being operated on, and (d) concomitant valve and aortic surgery. Therefore, new treatment strategies are required to protect the heart from PMI during cardiac surgery in order to improve clinical outcomes in these higher-risk patients ${ }^{4,5}$. In this regard, the endogenous cardioprotective phenomenon of ischaemic conditioning has been investigated as a treatment strategy for protecting the heart and improving clinical outcomes in patients undergoing cardiac surgery.

\section{Ischaemic conditioning: evolution of an endogenous cardioprotective strategy}

The myocardium possesses an innate ability to protect itself from the detrimental effects of acute ischaemia/reperfusion injury (IRI). This can be harnessed by subjecting the heart to one or more non-lethal cycles of brief (5-10 minutes) ischaemia and reperfusion, a phenomenon that has been termed "ischaemic preconditioning" (IPC) $)^{6-8}$. The concept of IPC was first discovered in a seminal study by Murry et al. in $1986^{6}$, when they made the surprising observation that four 5-minute episodes of regional myocardial ischaemia and reperfusion could dramatically reduce myocardial infarct (MI) size following a lethal period of ischaemia. IPC has since been reported to exist in every species and organ tested ${ }^{9}$. The IPC stimulus elicits two windows of cardioprotection: the first one (termed "classical IPC") begins immediately following the IPC stimulus and lasts for 2-3 hours ${ }^{6}$, and the second one (termed the "second window of protection" or SWOP and first described in 1993 $3^{10,11}$ ) appears 12-24 hours after the IPC stimulus and lasts for 48-72 hours. The mechanisms underlying classical IPC have been extensively investigated, are complex, and involve the activation of plasma membrane receptors (such as adenosine, opioids, acetylcholine, catecholamines, angiotensin II, bradykinin, and endothelin), the recruitment of a number of signal transduction pathways (such as nitric oxide-PKG, reperfusion injury salvage kinase ${ }^{12-14}$, and survivor activator factor enhancement ${ }^{15-18}$ ), the inhibition of mitochondrial permeability transition pore (MPTP) opening ${ }^{19-25}$, and the prevention of necrotic and apoptotic cell death. The delayed cardioprotective effect of the SWOP has been shown to be mediated by the transcription of several new proteins such as inducible nitric oxide synthase, heat shock proteins, and cyclo-oxygenase- $2^{26}$.

One major disadvantage of IPC is the need to apply the stimulus prior to the index ischaemic insult, which is not possible in acute myocardial infarction (AMI). In this regard, Zhao et al. in $2003^{27}$ found that applying three 30 -second cycles of ischaemia and reperfusion to the canine heart at the onset of reperfusion following a period of index ischaemia reduced MI size to a level on a par with IPC, a phenomenon that was termed "ischaemic postconditioning" (IPost) and that has provided a therapeutic strategy to protect the heart following $\mathrm{AMI}^{28}$. The signalling pathways underlying IPost are similar to classical IPC, although there are some differences ${ }^{7,9,29-31}$.

Crucially, both IPC and IPost require an invasive stimulus to be applied directly to the heart, thereby limiting their clinical application. In 1993, Pryzklenk et al. ${ }^{32}$ made the intriguing discovery that applying the IPC stimulus (four 5-minute cycles of ischaemia and reperfusion) to the circumflex coronary artery could reduce MI size following a sustained occlusion of the left anterior descending coronary artery, demonstrating that the protection elicited by ischaemic conditioning could be transferred from one region of the heart to another, a phenomenon which has been termed "remote ischaemic conditioning" $(\text { RIC })^{32-35}$. Subsequent experimental studies demonstrated that the heart could be protected against AMI by applying the IPC stimulus to an organ or tissue remote from the heart, extending the concept of RIC to inter-organ ischaemic conditioning. The discovery that RIC could be induced by applying one or more cycles of brief ischaemia and reperfusion to the hind limb to reduce MI size ${ }^{36,37}$ facilitated the translation of RIC into the clinical setting with the use of a blood pressure cuff placed on the upper arm or thigh to induce one or more cycles of brief ischaemia and reperfusion to the limb (termed "limb RIC") 38 . The mechanisms underlying limb RIC are not known, especially those conveying the cardioprotective signal from the limb to the heart. The current paradigm suggests that the limb RIC stimulus generates a blood-borne transferrable factor, which then activates protective signal transduction pathways common to IPC and IPost, but the identity of the factor or factors remains unknown ${ }^{39}$. Several potential candidates have been proposed, including nitrite ${ }^{40}$, miRNA144 ${ }^{41}$, and $\mathrm{SDF}^{42}$, but conclusive evidence for their role as the mediators of RIC is lacking. Interestingly, the neural pathway to the limb has to be intact for RIC to be effective ${ }^{43,44}$, suggesting that the underlying factor or factors may be a neurotransmitter or neuropeptide.

\section{Ischaemic preconditioning and postconditioning in cardiac surgery}

The first study to translate IPC into the clinical setting was by Yellon et al. in 1993 ${ }^{45}$; they demonstrated that subjecting the heart to two 3-minute cycles of global ischaemia and reperfusion by clamping and unclamping the aorta was able to preserve myocardial ATP levels ${ }^{45}$ and reduce $\mathrm{PMI}^{46}$ following cardiac surgery. Since this pioneering study, a number of clinical studies have confirmed the cardioprotective effect of direct IPC in patients undergoing cardiac surgery, and a subsequent meta-analysis found 
that IPC was able to reduce ventricular arrhythmias, lower inotrope use, and shorten intensive care unit stay when compared to control ${ }^{47}$. In 2007, Luo et al. ${ }^{48}$ were the first to apply IPost to the setting of cardiac surgery when they showed that applying IPost at the time of aortic unclamping, by re-clamping the aorta after 30 seconds and then unclamping it for 30 seconds, a cycle that was repeated twice, reduced PMI in children undergoing cardiac surgery for Tetralogy of Fallot. A number of clinical studies have confirmed the efficacy of this IPost protocol in children and adults undergoing cardiac surgery ${ }^{49,50}$. Given the invasive nature of the IPC and IPost protocols and the risk of thromboembolism from serial clamping and unclamping of the aorta, neither IPC nor IPost has been applied in the clinical setting.

\section{Limb remote ischaemic conditioning in cardiac surgery}

The first clinical trial to investigate limb RIC as a cardioprotective intervention in the setting of cardiac surgery was a small study of only eight patients by Günaydin et al. in $2000^{51}$. They found that limb RIC, comprising two cycles of 3-minute arm ischaemia and 2-minute arm reperfusion, did not reduce PMI during cardiac surgery. In 2002, Kharbanda et al. ${ }^{38}$ characterised the use of a blood pressure cuff to non-invasively deliver limb RIC (three 5-minute cycles of ischaemia and reperfusion), demonstrating MI size reduction in a porcine model of acute myocardial IRI and improved endothelial function in human volunteers. The first clinical study to report a cardioprotective effect with limb RIC (three 5-minute cycles of arm ischaemia and reperfusion) was by Cheung et al. ${ }^{52}$, who found less PMI in children undergoing corrective cardiac surgery for congenital heart disease. Our group was the first to demonstrate less PMI (43\% reduction in serum troponin $\mathrm{T}$ release over a 72 -hour postoperative period) in adult patients undergoing CABG surgery with limb RIC (three 5-minute cycles of arm ischaemia and reperfusion) when compared to control $^{53}$. Since these early studies, there have been a number of small positive studies confirming the cardioprotective effect of limb RIC in the setting of cardiac surgery, although there have also been several neutral studies (for comprehensive reviews, see 8,54-58). In a follow-up study of 329 CABG patients, Thielmann et al. ${ }^{59}$ found that limb RIC (three 5-minute cycles of arm ischaemia and reperfusion) reduced PMI and actually reduced all-cause mortality at 1.5 years by $73 \%$ when compared to control. However, this study was not prospectively designed or powered to test the effects of limb RIC on major clinical outcomes following cardiac surgery.

The effect of limb RIC on clinical outcomes following cardiac surgery has been recently investigated in three large prospective multicentre randomised controlled clinical trials, all of which failed to demonstrate any benefit with limb RIC on either PMI or major clinical outcomes. The first of these was a South Korean clinical study of 1,280 patients undergoing cardiac surgery (CABG, valve, congenital heart disease, and aortic surgery), published in 2014 by Hong et al. ${ }^{60}$. They found in adult patients that limb RIC (four 5-minute cycles of ischaemia and reperfusion administered twice to the upper limb before and after cardiopulmonary bypass) failed to improve the large primary composite endpoint (in-patient major adverse outcomes, including death, MI, arrhythmia, stroke, coma, renal failure or dysfunction, respiratory failure, cardiogenic shock, gastrointestinal complications, and multi-organ failure). The German RIPHeart clinical trial did not find any improvement in the in-patient primary composite endpoint (death, non-fatal MI, stroke, and acute kidney injury) with limb RIC (four 5-minute cycles of arm ischaemia and reperfusion) in 1,385 adult patients undergoing cardiac surgery (CABG, valve, and aortic) ${ }^{61}$. Finally, the UK ERICCA clinical trial randomised 1,612 higher-risk adult patients undergoing $\mathrm{CABG}$ with or without valve surgery (Additive Euroscore $\geq 5$ ) to either limb RIC (four 5-minute cycles of arm ischaemia and reperfusion) or control and failed to find any improvement in the 1-year primary composite endpoint (cardiac death, non-fatal MI, stroke, and coronary revascularisation $)^{62}$.

\section{Why did limb remote ischaemic preconditioning fail to improve clinical outcomes following cardiac surgery?}

The potential reasons why the three large clinical trials failed to find any reduction in PMI or improvement in short-term and long-term clinical outcomes following cardiac surgery with limb RIC include the following:

\section{The clinical setting}

CABG surgery may not be the optimum clinical setting to test the cardioprotective effects of limb RIC given that the extent of acute myocardial injury sustained in this clinical setting is relatively small and the fact that cardioprotection has been optimised by improvements in surgical and anaesthetic techniques and the use of myocardial preservation strategies such as hypothermia and cardioplegia $^{63}$. Moreover, patients undergoing concomitant valve surgery may be less amenable to RIC cardioprotection when compared to $\mathrm{CABG}$ surgery alone owing to the larger surgical trauma. Furthermore, RIC has been demonstrated in experimental studies to protect the heart mainly against acute IRI, whereas during cardiac surgery the causes of myocardial injury are multi-factorial and include inflammation (from cardiopulmonary bypass), direct handling of the heart, and coronary micro-embolisation. As such, limb RIC may be more likely to be effective in the setting of AMI, in which the target for cardioprotection is greater. In this regard, several clinical studies have reported a reduction in MI size with limb RIC applied prior to either thrombolysis ${ }^{64}$ or primary $\mathrm{PCI}^{65-71}$ in ST-elevation MI (STEMI) patients, and a large European multicentre randomised controlled clinical trial (the CONDI2/ERIC-PPCI trial) is underway investigating whether limb RIC can reduce cardiac death and hospitalisation for heart failure at 1 year $^{72}$.

\section{The limb remote ischaemic preconditioning protocol}

Both the ERICCA and RIPHeart studies used a limb RIC protocol comprising four cycles of arm ischaemia and reperfusion ${ }^{61,62}$. Whether this is the optimal limb RIC protocol for cardioprotection in the setting of cardiac surgery is not known, as the RIC protocol has not been fully characterised in either the experimental animal or the clinical setting of acute myocardial IRI. Further work is therefore needed to investigate the most effective limb RIC (this 
has recently been done in mice ${ }^{73}$ ), a task which would be made easier if a biomarker could be discovered, which can be used to assess the cardioprotective efficacy of limb RIC. However, this will be difficult given that the mechanisms underlying limb RIC remain unclear. It has also been suggested that the failure to fully blind the limb RIC protocol may have contributed to the positive results of the smaller clinical studies ${ }^{74}$. Achieving full blinding of the limb RIC protocol in the setting of cardiac surgery can be challenging but is possible using a cuff attached to a dummy arm beneath the surgical drape ${ }^{75,76}$.

\section{Experimental animal models}

The majority of experimental studies demonstrating cardioprotection with limb RIC have used an experimental animal model of MI based on external occlusion of a coronary artery and have not tested limb RIC using a more relevant experimental animal model of cardiopulmonary bypass ${ }^{77}$. Furthermore, the experimental studies have for the most part included healthy, juvenile, small and large animals, making them far removed from the clinical setting of the typical middle-aged patient with IHD and multiple co-morbidities and co-medications (see below $)^{77,78}$.

\section{Co-morbidities}

A number of co-morbidities (such as age, diabetes, hypertension, and hypercholesterolaemia) have been shown in experimental animal studies to attenuate the cardioprotection induced by IPC and IPost, and emerging data suggest that limb RIC is also susceptible to this phenomenon ${ }^{77-80}$. Although some experimental studies have been able to recapitulate one individual comorbidity (using diabetic, hypertensive, or hypercholesterolaemic animal models) when assessing cardioprotection, most patients have multiple co-morbidities and, furthermore, they are often on multiple treatments for their co-morbidities (anti-diabetic, anti-hypertensive, and lipid-lowering medication)_reproducing this in animal models will be extremely challenging ${ }^{58}$.

\section{Co-medications}

Patients undergoing CABG surgery receive a number of different medications, many of which have the potential to interfere with the cardioprotection elicited by limb RIC-these include antidiabetic medications, statins, angiotensin-converting enzyme inhibitors or angiotensin receptor blockers, calcium antagonists, beta-blockers, nitrates, morphine, inhaled anaesthetics, and propofol $^{78}$. Of these, it has been suggested that the use of the intravenous anaesthetic propofol may have contributed to the failure of limb RIC to reduce PMI and improve clinical outcomes in the ERICCA and RIPHeart studies, given that over $90 \%$ of patients received propofol ${ }^{61,62}$; however, the data supporting this proposition are not conclusive. The first clinical study to draw attention to the potential confounding role of propofol on limb RIC was by Kottenberg et al..$^{81}$, who showed that limb RIC was cardioprotective in the presence of isoflurane anaesthesia $(n=19$ patients), but not propofol anaesthesia ( $n=14$ patients) in the setting of CABG surgery. Interestingly, propofol anaesthesia in the absence of limb RIC had no cardioprotective effect, suggesting that propofol was somehow antagonising the cardioprotective effect of limb RIC in the setting of cardiac surgery. More recently, Bautin et $a l .^{82}$ showed in 48 patients (12 per group) undergoing aortic valve replacement surgery that the cardioprotective effect of limb RIC observed with sevoflurane anaesthesia was absent in the presence of propofol. In contrast, there have been several clinical studies reporting cardioprotection with limb RIC in cardiac surgery patients in the presence of propofol anaesthesia ${ }^{53,83,84}$. Furthermore, there are experimental data suggesting that propofol itself can reduce MI $\operatorname{size}^{85}$ and is cardioprotective in a porcine model of cardiopulmonary bypass ${ }^{86}$ through anti-oxidant and mito-protective mechanisms. Therefore, a suitably powered prospective randomised controlled clinical trial is required to test whether propofol anaesthesia antagonises the cardioprotective effect of limb RIC in the setting of cardiac surgery when compared to volatile anaesthesia.

\section{Conclusions}

Ischaemic conditioning has been investigated as an endogenous cardioprotective strategy for protecting the myocardium against PMI and improving clinical outcomes following cardiac surgery. Of these, IPC and IPost have been reported to reduce PMI, but, as they require direct application of the cardioprotective stimulus to the heart and because of the potential thromboembolic risk from repetitive clamping of the aorta, their clinical application has been limited. In this regard, limb RIC, which allows the cardioprotective stimulus to be applied to the arm or leg by simply inflating a blood pressure cuff placed on the upper arm or thigh, has facilitated RIC's use in the clinical setting of cardiac surgery, where it has been shown to reduce PMI. However, three large multicentre clinical studies have failed to find improved short-term and long-term clinical outcomes with limb RIC following cardiac surgery, questioning the role of limb RIC in the setting of cardiac surgery. Further studies are required to investigate why limb RIC failed to improve clinical outcomes in this clinical setting. However, limb RIC still has therapeutic potential to protect the heart in AMI patients and may also protect non-cardiac organs (such as the brain, liver, and kidney) from acute IRI.

\section{Competing interests}

The authors declare that they have no competing interests.

\section{Grant information}

This work was supported by the British Heart Foundation (FS/10/039/28270), the Rosetrees Trust, Duke-NUS Medical School, and the National Institute for Health Research University College London Hospitals Biomedical Research Centre.

The funders had no role in study design, data collection and analysis, decision to publish, or preparation of the manuscript. 
1. Mohr FW, Morice M, Kappetein AP, et al.: Coronary artery bypass graft surgery versus percutaneous coronary intervention in patients with three-vessel disease and left main coronary disease: 5 -year follow-up of the randomised, clinical SYNTAX trial. Lancet. 2013; 381(9867): 629-38. PubMed Abstract | Publisher Full Text

2. F Sipahi I, Akay MH, Dagdelen S, et al:: Coronary artery bypass grafting vs percutaneous coronary intervention and long-term mortality and morbidity in multivessel disease: meta-analysis of randomized clinical trials of the arterial grafting and stenting era. JAMA Intern Med. 2014; 174(2): 223-30. PubMed Abstract | Publisher Full Text | F1000 Recommendation

3. Biancari F, Kangasniemi OP, Aliasim Mahar M, et al.: Changing risk of patients undergoing coronary artery bypass surgery. Interact Cardiovasc Thorac Surg. 2009; 8(1): 40-4

PubMed Abstract | Publisher Full Text

4. Hausenloy DJ, Boston-Griffiths E, Yellon DM: Cardioprotection during cardiac surgery. Cardiovasc Res. 2012; 94(2): 253-65.

PubMed Abstract | Publisher Full Text | Free Full Text

5. Hausenloy DJ, Yellon DM: "Conditional Conditioning" in cardiac bypass surgery. Basic Res Cardiol. 2012; 107(3): 258. PubMed Abstract | Publisher Full Text

6. F Murry CE, Jennings RB, Reimer KA: Preconditioning with ischemia: a delay of lethal cell injury in ischemic myocardium. Circulation. 1986; 74(5): 1124-36. PubMed Abstract | Publisher Full Text | F1000 Recommendation

7. Hausenloy DJ, Yellon DM: Preconditioning and postconditioning: new trategies for cardioprotection. Diabetes Obes Metab. 2008; 10(6): 451-9. PubMed Abstract | Publisher Full Tex

8. Hausenloy DJ, Barrabes JA, Botker HE, et al.: Ischaemic conditioning and targeting reperfusion injury: a $\mathbf{3 0}$ year voyage of discovery. Basic Res Cardiol. 2016; 111(6): 70.

PubMed Abstract | Publisher Full Text | Free Full Text

9. Hausenloy DJ: Cardioprotection techniques: preconditioning, postconditioning and remote conditioning (basic science). Curr Pharm Des. 2013; 19(25): 4544-63.

PubMed Abstract | Publisher Full Text

10. Kuzuya T, Hoshida S, Yamashita N, et al:: Delayed effects of sublethal ischemia on the acquisition of tolerance to ischemia. Circ Res. 1993; 72(6): 1293-9. PubMed Abstract | Publisher Full Text

11. Marber MS, Latchman DS, Walker JM, et al: Cardiac stress protein elevation 24 hours after brief ischemia or heat stress is associated with resistance to myocardial infarction. Circulation. 1993; 88(3): 1264-72. PubMed Abstract | Publisher Full Text

12. Hausenloy DJ, Yellon DM: New directions for protecting the heart against ischaemia-reperfusion injury: targeting the Reperfusion Injury Salvage Kinase (RISK)-pathway. Cardiovasc Res. 2004; 61(3): 448-60. PubMed Abstract | Publisher Full Text

13. Hausenloy DJ, Yellon DM: Reperfusion injury salvage kinase signalling: taking a RISK for cardioprotection. Heart Fail Rev. 2007; 12(3-4): 217-34. PubMed Abstract | Publisher Full Text

14. Hausenloy DJ, lliodromitis EK, Andreadou I, et al.: Investigating the signal transduction pathways underlying remote ischemic conditioning in the porcine heart. Cardiovasc Drugs Ther. 2012; 26(2): 87-93. PubMed Abstract | Publisher Full Text

15. F Lacerda L, Somers S, Opie LH, et al.: Ischaemic postconditioning protects against reperfusion injury via the SAFE pathway. Cardiovasc Res. 2009; 84(2): $201-8$.

PubMed Abstract | Publisher Full Text | F1000 Recommendation

16. Lecour S: Activation of the protective Survivor Activating Factor Enhancement (SAFE) pathway against reperfusion injury: Does it go beyond the RISK pathway? J Mol Cell Cardiol. 2009; 47(1): 32-40. PubMed Abstract | Publisher Full Text

17. Lecour S: Multiple protective pathways against reperfusion injury: a SAFE path without Aktion? J Mol Cell Cardiol. 2009; 46(5): 607-9. PubMed Abstract | Publisher Full Text

18. Hausenloy DJ, Lecour S, Yellon DM: Reperfusion injury salvage kinase and survivor activating factor enhancement prosurvival signaling pathways in ischemic postconditioning: two sides of the same coin. Antioxid Redox Signal. 2011; 14(5): 893-907.

PubMed Abstract | Publisher Full Text

19. Hausenloy DJ, Maddock HL, Baxter GF, et al:: Inhibiting mitochondrial permeability transition pore opening: a new paradigm for myocardia preconditioning? Cardiovasc Res. 2002; 55(3): 534-43. PubMed Abstract | Publisher Full Text

20. Hausenloy DJ, Yellon DM: The mitochondrial permeability transition pore: its fundamental role in mediating cell death during ischaemia and reperfusion. J Mol Cell Cardiol. 2003; 35(4): 339-41. PubMed Abstract | Publisher Full Text
21. Hausenloy DJ, Duchen MR, Yellon DM: Inhibiting mitochondrial permeability transition pore opening at reperfusion protects against ischaemia-reperfusion injury. Cardiovasc Res. 2003; 60(3): 617-25.

PubMed Abstract | Publisher Full Text

22. Hausenloy D, Wynne A, Duchen M, et al.: Transient mitochondrial permeability transition pore opening mediates preconditioning-induced protection. Circulation. 2004; 109(14): 1714-7.

PubMed Abstract | Publisher Full Text

23. Hausenloy DJ, Yellon DM, Mani-Babu S, et al.: Preconditioning protects by inhibiting the mitochondrial permeability transition. Am J Physiol Heart Circ Physiol. 2004; 287(2): H841-9.

PubMed Abstract | Publisher Full Text

24. Shanmuganathan S, Hausenloy DJ, Duchen MR, et al.: Mitochondrial permeability transition pore as a target for cardioprotection in the human heart. Am J Physiol Heart Circ Physiol. 2005; 289(1): H237-42.

PubMed Abstract | Publisher Full Text

25. Hausenloy DJ, Ong SB, Yellon DM: The mitochondrial permeability transition pore as a target for preconditioning and postconditioning. Basic Res Cardiol. 2009; 104(2): 189-202.

PubMed Abstract | Publisher Full Text

26. Hausenloy DJ, Yellon DM: The second window of preconditioning (SWOP) where are we now? Cardiovasc Drugs Ther. 2010; 24(3): 235-54. PubMed Abstract | Publisher Full Text

27. Zhao ZQ, Morris CD, Budde JM, et al:: Inhibition of myocardial apoptosis reduces infarct size and improves regional contractile dysfunction during reperfusion. Cardiovasc Res. 2003; 59(1): 132-42.

PubMed Abstract | Publisher Full Text

28. F Staat $\mathrm{P}$, Rioufol $\mathrm{G}$, Piot $\mathrm{C}$, et al:: Postconditioning the human heart. Circulation. 2005; 112(14): 2143-8.

PubMed Abstract | Publisher Full Text | F1000 Recommendation

29. Hausenloy DJ, Yellon DM: Preconditioning and postconditioning: united at reperfusion. Pharmacol Ther. 2007; 116(2): 173-91.

PubMed Abstract | Publisher Full Text

30. Hausenloy DJ: Signalling pathways in ischaemic postconditioning. Thromb Haemost. 2009; 101(4): 626-34.

PubMed Abstract | Publisher Full Text

31. Hausenloy DJ, Yellon DM: Cardioprotective growth factors. Cardiovasc Res. 2009; 83(2): 179-94.

PubMed Abstract | Publisher Full Tex

32. F Przyklenk K, Bauer B, Ovize M, et al.: Regional ischemic 'preconditioning' protects remote virgin myocardium from subsequent sustained coronary occlusion. Circulation. 1993; 87(3): 893-9. PubMed Abstract | Publisher Full Text | F1000 Recommendation

33. Candilio L, Hausenloy DJ, Yellon DM: Remote ischemic conditioning: a clinical trial's update. J Cardiovasc Pharmacol Ther. 2011; 16(3-4): 304-12. PubMed Abstract | Publisher Full Text

34. Candilio L, Malik A, Hausenloy DJ: Protection of organs other than the heart by remote ischemic conditioning. J Cardiovasc Med (Hagerstown). 2013; 14(3): 193-205

PubMed Abstract | Publisher Full Text

35. F Remote Preconditioning Trialists' Group, Healy DA, Khan WA, et al: Remote preconditioning and major clinical complications following adult cardiovascular surgery: systematic review and meta-analysis. Int J Cardiol. 2014; 176(1): 20-31

PubMed Abstract | Publisher Full Text | F1000 Recommendation

36. Oxman $\mathrm{T}$, Arad $\mathrm{M}$, Klein $\mathrm{R}$, et al.: Limb ischemia preconditions the heart against reperfusion tachyarrhythmia. Am J Physiol. 1997; 273(4 Pt 2): H1707-12. PubMed Abstract

37. Birnbaum Y, Hale SL, Kloner RA: Ischemic preconditioning at a distance: reduction of myocardial infarct size by partial reduction of blood supply combined with rapid stimulation of the gastrocnemius muscle in the rabbit. Circulation. 1997; 96(5): 1641-6.

PubMed Abstract | Publisher Full Text

38. Kharbanda RK, Mortensen UM, White PA, et al:: Transient limb ischemia induces remote ischemic preconditioning in vivo. Circulation. 2002; 106(23): 2881-3. PubMed Abstract | Publisher Full Text

39. Hausenloy DJ, Yellon DM: Remote ischaemic preconditioning: underlying mechanisms and clinical application. Cardiovasc Res. 2008; 79(3): 377-86. PubMed Abstract | Publisher Full Text

40. F Rassaf T, Totzeck M, Hendgen-Cotta UB, et al.: Circulating nitrite contributes to cardioprotection by remote ischemic preconditioning. Circ Res. 2014; 114(10): 1601-10.

PubMed Abstract | Publisher Full Text | F1000 Recommendation

41. F Li J, Rohailla S, Gelber N, et al:: MicroRNA-144 is a circulating effector of 
remote ischemic preconditioning. Basic Res Cardiol. 2014; 109(5): 423 PubMed Abstract | Publisher Full Text | F1000 Recommendation

42. Davidson SM, Selvaraj $\mathrm{P}, \mathrm{He} \mathrm{D}$, et al:: Remote ischaemic preconditioning involves signalling through the SDF-1 $\alpha / C X C R 4$ signalling axis. Basic Res Cardiol. 2013; 108(5): 377 PubMed Abstract | Publisher Full Text

43. F Lim SY, Yellon DM, Hausenloy DJ: The neural and humoral pathways in remote limb ischemic preconditioning. Basic Res Cardiol. 2010; 105(5): 651-5. PubMed Abstract | Publisher Full Text | F1000 Recommendation

44. Pickard JM, Davidson SM, Hausenloy DJ, et al.: Co-dependence of the neural and humoral pathways in the mechanism of remote ischemic conditioning. Basic Res Cardiol. 2016; 111(4): 50.

PubMed Abstract | Publisher Full Text | Free Full Text

45. Yellon DM, Alkhulaifi AM, Pugsley WB: Preconditioning the human myocardium Lancet. 1993; 342(8866): 276-7.

PubMed Abstract | Publisher Full Text

46. Jenkins DP, Pugsley WB, Alkhulaifi AM, et al.: Ischaemic preconditioning reduces troponin $\mathrm{T}$ release in patients undergoing coronary artery bypass surgery. Heart. 1997; 77(4): 314-8. PubMed Abstract | Publisher Full Text | Free Full Text

47. Walsh SR, Tang TY, Kullar $\mathrm{P}$, et al.: Ischaemic preconditioning during cardiac surgery: systematic review and meta-analysis of perioperative outcomes in randomised clinical trials. Eur J Cardiothorac Surg. 2008; 34(5): 985-94. PubMed Abstract | Publisher Full Text

48. Luo W, Li B, Lin G, et al:: Postconditioning in cardiac surgery for tetralogy of Fallot. J Thorac Cardiovasc Surg. 2007; 133(5): 1373-4. PubMed Abstract | Publisher Full Text

49. Luo W, Li B, Chen R, et al.: Effect of ischemic postconditioning in adult valve replacement. Eur J Cardiothorac Surg. 2008; 33(2): 203-8. PubMed Abstract | Publisher Full Text

50. Li B, Chen R, Huang R, et al.: Clinical benefit of cardiac ischemic postconditioning in corrections of tetralogy of Fallot. Interact Cardiovasc Thorac Surg. 2009; 8(1): $17-21$.

PubMed Abstract | Publisher Full Text

51. Gunaydin B, Cakici I, Soncul H, et al.: Does remote organ ischaemia trigger cardiac preconditioning during coronary artery surgery? Pharmacol Res. 2000; 41(4): 493-6.

PubMed Abstract | Publisher Full Text

52. F Cheung MM, Kharbanda RK, Konstantinov IE, et al:: Randomized controlled trial of the effects of remote ischemic preconditioning on children undergoing cardiac surgery: first clinical application in humans. J Am Coll Cardiol. 2006 47(11): 2277-82.

PubMed Abstract | Publisher Full Text | F1000 Recommendation

53. F Hausenloy DJ, Mwamure PK, Venugopal V, et al.: Effect of remote ischaemic preconditioning on myocardial injury in patients undergoing coronary artery bypass graft surgery: a randomised controlled trial. Lancet. 2007; 370(9587): $575-9$.

PubMed Abstract | Publisher Full Text | F1000 Recommendation

54. Pickard JM, Botker HE, Crimi G, et al.: Remote ischemic conditioning: from experimental observation to clinical application: report from the 8th Biennial Hatter Cardiovascular Institute Workshop. Basic Res Cardiol. 2015; 110(1): 453. PubMed Abstract | Publisher Full Text | Free Full Text

55. F Sivaraman V, Pickard JM, Hausenloy DJ: Remote ischaemic conditioning: cardiac protection from afar. Anaesthesia. 2015; 70(6): 732-48.

PubMed Abstract | Publisher Full Text | Free Full Text | F1000 Recommendation

56. Bulluck H, Hausenloy DJ: Ischaemic conditioning: are we there yet? Heart. 2015; 101(13): 1067-77.

PubMed Abstract | Publisher Full Text

57. Hausenloy DJ, Yellon DM: Ischaemic conditioning and reperfusion injury. Nat Rev Cardiol. 2016; 13(4): 193-209.

PubMed Abstract | Publisher Full Text

58. Hausenloy DJ, Garcia-Dorado D, Erik Botker H, et al:: Novel targets and future strategies for acute cardioprotection: Position Paper of the European Society of Cardiology Working Group on Cellular Biology of the Heart. Cardiovasc Res. 2017.

PubMed Abstract | Publisher Full Text

59. F Thielmann M, Kottenberg E, Kleinbongard $\mathrm{P}$, et al:: Cardioprotective and prognostic effects of remote ischaemic preconditioning in patients undergoing coronary artery bypass surgery: a single-centre randomised, undergoing coronary artery bypass surgery: a single-centre randc PubMed Abstract | Publisher Full Text | F1000 Recommendation

60. $\mathrm{F}$ Hong DM, Lee $\mathrm{EH}, \mathrm{Kim} \mathrm{HJ}$, et al:: Does remote ischaemic preconditioning with postconditioning improve clinical outcomes of patients undergoing cardiac surgery? Remote Ischaemic Preconditioning with Postconditioning Outcome Trial. Eur Heart J. 2014; 35(3): 176-83.

PubMed Abstract | Publisher Full Text | F1000 Recommendation

61. F Meybohm P, Bein B, Brosteanu O, et al.: A Multicenter Trial of Remote Ischemic Preconditioning for Heart Surgery. N Engl J Med. 2015; 373(15): 1397-407.

PubMed Abstract | Publisher Full Text | F1000 Recommendation
62. F Hausenloy DJ, Candilio L, Evans R, et al.: Remote Ischemic Preconditioning and Outcomes of Cardiac Surgery. N Engl J Med. 2015; 373(15): 1408-17. PubMed Abstract | Publisher Full Text | F1000 Recommendation

63. Venugopal V, Ludman A, Yellon DM, et al.: 'Conditioning' the heart during surgery. Eur J Cardiothorac Surg. 2009; 35(6): 977-87.

PubMed Abstract | Publisher Full Text

64. Yellon DM, Ackbarkhan AK, Balgobin V, et al:: Remote Ischemic Conditioning Reduces Myocardial Infarct Size in STEMI Patients Treated by Thrombolysis. J Am Coll Cardiol. 2015; 65(25): 2764-5. PubMed Abstract | Publisher Full Text

65. F Botker HE, Kharbanda R, Schmidt MR, et al.: Remote ischaemic conditioning before hospital admission, as a complement to angioplasty, and effect on myocardial salvage in patients with acute myocardial infarction: a randomised trial. Lancet. 2010; 375(9716): 727-34. PubMed Abstract | Publisher Full Text | F1000 Recommendation

66. F Rentoukas I, Giannopoulos G, Kaoukis A, et al:: Cardioprotective role of remote ischemic periconditioning in primary percutaneous coronary intervention: enhancement by opioid action. JACC Cardiovasc Interv. 2010; 3(1): $49-55$.

PubMed Abstract | Publisher Full Text | F1000 Recommendation

67. Crimi G, Pica S, Raineri C, et al.: Remote ischemic post-conditioning of the lower limb during primary percutaneous coronary intervention safely reduces enzymatic infarct size in anterior myocardial infarction: a randomized controlled trial. JACC Cardiovasc Interv. 2013; 6(10): 1055-63. PubMed Abstract | Publisher Full Text

68. White SK, Frohlich GM, Sado DM, et al.: Remote ischemic conditioning reduces myocardial infarct size and edema in patients with ST-segment elevation myocardial infarction. JACC Cardiovasc Interv. 2015; 8(1 Pt B): 178-88. PubMed Abstract | Publisher Full Text

69. F Prunier F, Angoulvant D, Saint Etienne C, et al.: The RIPOST-MI study, assessing remote ischemic perconditioning alone or in combination with local ischemic postconditioning in ST-segment elevation myocardial infarction. Basic Res Cardiol. 2014; 109(2): 400.

PubMed Abstract | Publisher Full Text | F1000 Recommendation

70. F Eitel I, Stiermaier T, Rommel KP, et al:: Cardioprotection by combined intrahospital remote ischaemic perconditioning and postconditioning in STelevation myocardial infarction: the randomized LIPSIA CONDITIONING trial. Eur Heart J. 2015; 36(44): 3049-57.

PubMed Abstract | Publisher Full Text | F1000 Recommendation

71. F Liu Z, Zhao L, Hong D, et al.: Remote ischaemic preconditioning reduces myocardial ischaemic reperfusion injury in patients with ST-elevation myocardial infarction undergoing primary percutaneous coronary intervention. Acta Cardiol. 2016; 71(5): 596-603.

PubMed Abstract | Publisher Full Text | F1000 Recommendation

72. Hausenloy DJ, Kharbanda R, Rahbek Schmidt M, et al:: Effect of remote ischaemic conditioning on clinical outcomes in patients presenting with an ST-segment elevation myocardial infarction undergoing primary percutaneous coronary intervention. Eur Heart J. 2015; 36(29): 1846-8. PubMed Abstract

73. F Johnsen J, Pryds K, Salman R, et al:: The remote ischemic preconditioning algorithm: effect of number of cycles, cycle duration and effector organ mas on efficacy of protection. Basic Res Cardiol. 2016; 111(2): 10.

PubMed Abstract | Publisher Full Text | F1000 Recommendation

74. Pilcher JM, Young P, Weatherall M, et al:: A systematic review and meta-analysis of the cardioprotective effects of remote ischaemic preconditioning in open cardiac surgery. J R Soc Med. 2012; 105(10): 436-45. PubMed Abstract | Publisher Full Text | Free Full Text

75. Rahman IA, Mascaro JG, Steeds RP, et al:: Remote ischemic preconditioning in human coronary artery bypass surgery: from promise to disappointment? Circulation. 2010; 122(11 Suppl): S53-9. PubMed Abstract | Publisher Full Text

76. Young PJ, Dalley P, Garden A, et al.: A pilot study investigating the effects of remote ischemic preconditioning in high-risk cardiac surgery using a randomised controlled double-blind protocol. Basic Res Cardiol. 2012; 107(3): 256. PubMed Abstract | Publisher Full Text

77. Lecour S, Botker HE, Condorelli G, et al.: ESC working group cellular biology of the heart: position paper: improving the preclinical assessment of nove cardioprotective therapies. Cardiovasc Res. 2014; 104(3): 399-411. PubMed Abstract | Publisher Full Text | Free Full Text

78. Ferdinandy P, Hausenloy DJ, Heusch G, et al.: Interaction of risk factors, comorbidities, and comedications with ischemia/reperfusion injury and cardioprotection by preconditioning, postconditioning, and remote conditioning. Pharmacol Rev. 2014; 66(4): 1142-74. PubMed Abstract | Publisher Full Text

79. Sivaraman V, Hausenloy DJ, Wynne AM, et al.: Preconditioning the diabetic human myocardium. J Cell Mol Med. 2010; 14(6B): 1740-6. PubMed Abstract | Publisher Full Text | Free Full Text

80. F Whittington $\mathrm{HJ}$, Harding I, Stephenson $\mathrm{Cl}$, et al.: Cardioprotection in the aging, diabetic heart: the loss of protective Akt signalling. Cardiovasc Res. 
2013; 99(4): 694-704

PubMed Abstract | Publisher Full Text | Free Full Text | F1000 Recommendation

81. Kottenberg E, Thielmann M, Bergmann L, et al:: Protection by remote ischemic preconditioning during coronary artery bypass graft surgery with isoflurane but not propofol - a clinical trial. Acta Anaesthesiol Scand. 2012; 56(1): 30-8. PubMed Abstract | Publisher Full Text

82. F Bautin AE, Galagudza MM, Tashkhanov DM, et al:: [Protein Kinase C Expression Following Remote Ischemic Preconditioning in Cardiac Surgery] Anesteziol Reanimatol. 2015; 60(6): 4-8. PubMed Abstract | F1000 Recommendation

83. F Venugopal V, Hausenloy DJ, Ludman A, et al:: Remote ischaemic preconditioning reduces myocardial injury in patients undergoing cardiac surgery with cold-blood cardioplegia: a randomised controlled trial. Heart.
2009; 95(19): 1567-71.

PubMed Abstract | Publisher Full Text | F1000 Recommendation

84. Li L, Luo W, Huang L, et al.: Remote perconditioning reduces myocardial injury in adult valve replacement: a randomized controlled trial. J Surg Res. 2010; 164(1): e21-6.

PubMed Abstract | Publisher Full Text

85. Javadov SA, Lim KH, Kerr PM, et al.: Protection of hearts from reperfusion injury by propofol is associated with inhibition of the mitochondrial permeability transition. Cardiovasc Res. 2000; 45(2): 360-9.

PubMed Abstract | Publisher Full Text

86. Lim KH, Halestrap AP, Angelini GD, et al:: Propofol is cardioprotective in a clinically relevant model of normothermic blood cardioplegic arrest and cardiopulmonary bypass. Exp Biol Med (Maywood). 2005; 230(6): 413-20. PubMed Abstract | Publisher Full Text 


\section{Open Peer Review}

\section{Current Peer Review Status:}

\section{Editorial Note on the Review Process}

Faculty Reviews are review articles written by the prestigious Members of Faculty Opinions. The articles are commissioned and peer reviewed before publication to ensure that the final, published version is comprehensive and accessible. The reviewers who approved the final version are listed with their names and affiliations.

\section{The reviewers who approved this article are:}

\section{Version 1}

\section{Petra Kleinbongard}

West German Heart and Vascular Centre, University of Essen Medical School, Essen, Germany Competing Interests: No competing interests were disclosed.

\section{Andreas Goetzenich} RWTH Aachen University, Aachen, Germany

Competing Interests: No competing interests were disclosed.

\section{Fabrice Prunier}

Department of Cardiology, CHU Angers, Angers, France

Competing Interests: No competing interests were disclosed.

The benefits of publishing with F1000Research:

- Your article is published within days, with no editorial bias

- You can publish traditional articles, null/negative results, case reports, data notes and more

- The peer review process is transparent and collaborative

- Your article is indexed in PubMed after passing peer review

- Dedicated customer support at every stage

For pre-submission enquiries, contact research@f1000.com 